\title{
Geochemistry and origin of Ordovician oils in the Rewapu Block of the Halahatang Oilfield (NW China)
}

\author{
You-Jun Tang ${ }^{1} \cdot$ Mei-Jun $\mathrm{Li}^{1,2} \cdot$ Rong-Hui Fang $^{2} \cdot$ Bao-Shou Zhang ${ }^{3} \cdot$ Zhe Yang $^{2} \cdot$ Da-Xiang He ${ }^{1} \cdot$ \\ Meng-Ru Li ${ }^{1}$
}

Received: 9 April 2018/Published online: 13 December 2018

(C) The Author(s) 2018

\begin{abstract}
The oils in the Rewapu Block of the Halahatang Oilfield in the Tarim Basin (northwestern China) were geochemically analyzed by gas chromatography-mass spectrometry to investigate their origin and possible secondary alteration. The physical properties and chemical compositions of these Ordovician oils vary greatly, ranging from light to extremely heavy oils. All these oils belong to one single population and were derived from same source kitchen/bed. The differences in their chemical compositions and physical properties mainly result from secondary alteration of oils that were charged during the early phase of trap formation. The thickness of Upper Ordovician and Silurian caprocks of oil reservoirs in the Rewapu Block is higher than that in the north part of the Halahatang region, and therefore, significant biodegradation process is prevented. Compared to heavy oils in the north part, the Rewapu oils are dominated by light oils with no 25-norhopanes and no GC-MS "hump" (UCM: unresolved complex mixture) on the chromatographic baselines. The heavy oils in Wells RP7 and RP101C were primarily influenced by water washing since apparent reduction of alkylated dibenzothiophenes was observed. The local geological background favored the water washing alteration. The reservoir geochemical study has practical application in hydrocarbon exploration and predicts the nature of oils in this oilfield.
\end{abstract}

Keywords Biodegradation $\cdot$ Water washing $\cdot$ Oil charging process $\cdot$ Ordovician $\cdot$ Tarim Basin

\section{Introduction}

The physical and chemical properties of in situ reservoir oils are primarily controlled by the nature/type, depositional environment/organic facies and the thermal maturation levels of organic matter in source rocks (Hunt 1979; Tissot and Welte 1984; Peters et al. 2005). In addition, the

Edited by Jie Hao

Mei-Jun Li

meijunli@cup.edu.cn

1 Key Laboratory of Exploration Technologies for Oil and Gas Resources (Yangtze University), Ministry of Education, College of Resources and Environment, Wuhan 430100, Hubei, China

2 State Key Laboratory of Petroleum Resources and Prospecting, College of Geosciences, China University of Petroleum, Beijing 102249, China

3 Research Institute of Petroleum Exploration and Development, Tarim Oilfield Company, PetroChina, Korla 841000 Xinjiang, China oil migration process, charging history and secondary alteration in reservoir and post-accumulation are also important factors modifying the nature and compositions of oils in the reservoirs (Connan 1984; Volkman et al. 1984; England et al. 1987; Peters and Moldowan 1993; Cubitt and England 1995). For oils derived from the same oil source kitchen/bed, the variations in physical properties and chemical compositions are mainly determined by oil migration processes, oil charging histories and secondary alteration.

Halahatang Oilfield, located in the Tabei Uplift, is one of the most prolific oilfields of the Paleozoic carbonate reservoirs in the cratonic region of the Tarim Basin, northwestern China (Zhu et al. 2012; Chang et al. 2013a, b; Zhao et al. 2015; Huang et al. 2016; Liu et al. 2016; Xiao et al. 2016; Fang et al. 2017a; Li et al. 2018). Petroleum with different densities, including ultra-heavy oils, heavy oils, normal oils, light oils and condensates, has been discovered in this region during recent oil exploration (Zhu et al. 2012; Chang et al. 2013a; Cui et al. 2013; Xiao et al. 2016; Li et al. 2018). The Rewapu Block, located in the 
south part of the Halahatang area, is dominated by normal and light oils with minor heavy oils in some wells. The oil reservoirs mainly occur within Ordovician strata, including the Upper Ordovician Lianglitage $\left(\mathrm{O}_{3} l\right)$, Middle Ordovician Yijianfang $\left(\mathrm{O}_{2} y\right)$ and Lower-Middle Ordovician Yingshan $\left(\mathrm{O}_{1-2} \mathrm{y}\right)$ Formations.

The origin of Paleozoic petroleum in the cratonic region of the Tarim Basin has long been a controversial issue. In light of the sulfur and carbon isotope compositions, the occurrence of aryl isoprenoids and characteristics of biomarkers, Ma et al. (2003), Sun et al. (2003) and Cai et al. $(2015,2016)$ proposed that most of the oils in the Tazhong Uplift, Well YM2 in the Yingmaili area and Well TD2 in the eastern Tarim Basin were probably derived from Cambrian source rocks. However, previous studies show that the oils in the Halahatang area and Tabei Uplift were mainly derived from Middle-Upper Ordovician source rocks (e.g., Zhang et al. 2002; Zhang and Huang 2005; Jing 2006; Mi et al. 2007; Wang et al. 2008; Li et al. 2010; Chang et al. 2013a). The argument may continue, but it has been widely accepted that two types of petroleum resources that were derived from Cambrian-Lower Ordovician and Middle-Upper Ordovician occur in the cratonic region of the Tarim Basin (e.g., Zhang et al. 2002; Zhang and Huang 2005; Li et al. 2012).

The results of oil family classification indicated that most of the oils in the Paleozoic reservoirs in the Halahatang region are genetically identical and should be grouped as one single oil family (Zhang et al. 2000; Zhang and Huang 2005; Chang et al. 2013a; Xiao et al. 2016; Li et al. 2018). The oil migration orientation and filling pathway traced by various molecular geochemical indicators show that oils mainly migrated from south to north and the predicted source kitchen is located in the Manxi Low Uplift (Chang et al. 2013b; Xiao et al. 2016; Li et al. 2018). Combining with the homogenization temperature of fluid inclusions and reconstructed burial and geothermal histories, previous studies show that the Ordovician carbonate reservoirs have experienced two major oil charging events. These two phases of oil charging and entrapment timing are the Middle to Late Silurian and the Miocene to Pliocene, respectively (Chang et al. 2013b; Xiao et al. 2016; Li et al. 2018).

Moreover, most of the Ordovician carbonate oils in the Tabei Uplift of the Tarim Basin show both intact $n$-alkane series and an evident GC-MS "hump" (UCM: unresolved complex mixture) with 25-norhopane series compounds (Wang et al. 2008; Chang et al. 2013a). The coexistence of $n$-alkanes and UCM/25-norhopanes indicates that there are at least two oil filling events for Ordovician reservoirs in the Tabei Uplift. The early charged oils must have been severely biodegraded within a reservoir and then were mixed with later charged undegraded oils in the same reservoir (Wang et al. 2008). Similar phenomena have also been reported in other studies (Volkman et al. 1983; Alexander et al. 1983; Philp 1983; Sofer et al. 1986; Talukdar et al. 1988; Waples and Machihara 1991; Cai et al. 2017).

Biodegradation is a well-documented process that modifies the physical properties and chemical compositions of reservoir oils (Huang et al. 2003). Much work has been done on the formation of heavy oil and solid bitumen via biodegradation in the Tarim Basin (Tian et al. 2008; Chang et al. 2012; Zhu et al. 2012; Zhang et al. 2014; Cheng et al. 2016). Recent research also shows that the physical properties and chemical compositions of oils in this region are jointly controlled by the development of caprocks, the extent of mixing of biodegraded and unbiodegraded oils, and the most recent preservation conditions ( $\mathrm{Li}$ et al. 2018).

While previous studies are mainly focused on the oil family classification, oil migration orientation, filling pathway, timing and episodes of oil entrapment in the entire Halahatang Oilfield, little work has been done on the water washing process, which is another principal process that changes the chemical compositions of reservoir oils. Both geochemical discoveries and laboratory experiments suggested that one of the main chemical effects of water washing is the removal of the more water-soluble components of petroleum, especially low molecular weight (LMW) aromatic compounds (Palmer 1984; Lafargue and Barker 1988; Kuo 1994; Lafargue and Le Thiez 1996; Hemptinne et al. 2001). Terpane and sterane biomarkers are little affected by water washing (Palmer 1984). The effect of water washing can be readily illustrated by laboratory experiments. However, it is a little difficult to assess the extent of water washing for natural oils because it is often associated with biodegradation (Huang et al. 2003).

This study conducts comprehensive organic geochemical investigation into the chemical compositions of oils in the Rewapu Block and attempts to get an insight into the differences in physical properties and compositions of molecular biomarkers in these oils. Combing the regional oil charging history of the Halahatang Oilfield and the local geological background, this paper investigated the effects of biodegradation, water washing, the thickness of caprocks and oil charging history on the changes of chemical compositions of reservoir oils. The results may have practical use for oil exploration and development in this region and can also provide an example for the study of reservoir geochemistry in other blocks. 


\section{Samples and geological settings}

A total of 23 oil samples were collected from the Rewapu Block of the Halahatang Oilfield in the Tabei Uplift of the Tarim Basin. Four heavy oils from the Ha6 Block in the northern part of the Halahatang region were also analyzed for comparison (Table 1). All oils are produced from the Ordovician carbonate reservoirs. These oils cover a wide spectrum of densities, ranging from light oils to ultra-heavy oils (Table 1). Numerous studies by previous authors have summarized the geological background for the Paleozoic carbonate petroleum reservoirs in the Tabei Uplift (Zhang et al. 2002; Zhang and Huang 2005; Wang et al. 2008; Li et al. 2011; Zhu et al. 2012; Zhao et al. 2015). The Tabei Uplift is one of the main structural belts and the main part of the cratonic region of the Tarim Basin (Fig. 1). The
Tabei Uplift was initially formed during Late Proterozoic to Devonian periods. Carboniferous to Permian Formations are mainly composed of interbedded strata of marine and terrestrial rocks. The uplift subsided continuously during the Jurassic to Paleogene and then experienced a rapid subsidence from the Neogene to the Quaternary.

Most of the Ordovician reservoirs in the Halahatang Oilfield are distributed in the Lower to Upper Ordovician Yingshan, Yijianfang and Lianglitage Formations, which were all deposited in an open platform facies, comprising brown-gray arenite, bioclastic limestone and algal limestone interbedded with oolitic limestone and micrite limestone (Zhu et al. 2012).

Table 1 Density and bulk geochemical compositions for oils from the Rewapu Block and neighboring areas of the Halahatang Oilfield in the Tarim Basin (DBTs are alkylated dibenzothiophenes)

\begin{tabular}{|c|c|c|c|c|c|c|c|c|c|}
\hline Well no. & Depth, m & Fm. & $\begin{array}{l}\text { Density, } \\
\mathrm{g} / \mathrm{cm}^{3}\end{array}$ & $\begin{array}{l}\text { Saturated, } \\
\text { wt } \%\end{array}$ & $\begin{array}{l}\text { Aromatics, } \\
\text { wt } \%\end{array}$ & $\begin{array}{l}\text { Resins, } \\
\text { wt } \%\end{array}$ & $\begin{array}{l}\text { Asphaltenes, } \\
\text { wt } \%\end{array}$ & $\begin{array}{l}\text { Saturated/ } \\
\text { aromatics }\end{array}$ & $\begin{array}{l}\text { DBTs, } \\
\mu \mathrm{g} / \mathrm{g}\end{array}$ \\
\hline $\mathrm{Ha} 7$ & $6631.1-6645.2$ & $\mathrm{O}_{1-2} \mathrm{y}$ & $\approx 1.00$ & 18.8 & 27.4 & 13.5 & 40.3 & 0.7 & 174 \\
\hline Ha7-1 & $6568.0-5275.0$ & $\mathrm{O}_{2} \mathrm{y}$ & 0.9679 & 67.6 & 20.0 & 7.60 & 4.80 & 3.4 & 1502 \\
\hline Ha7-7 & $6575.0-6650.0$ & $\mathrm{O}_{2} \mathrm{y}$ & 0.9420 & 66.6 & 26.1 & 3.90 & 3.40 & 2.6 & 1063 \\
\hline Ha9-6 & $6529.0-6655.0$ & $\mathrm{O}_{3} l$ & 0.9410 & 55.8 & 19.6 & 3.30 & 21.3 & 2.8 & 1191 \\
\hline RP101C & $6648.0-7233.0$ & $\mathrm{O}_{2} \mathrm{y}$ & 0.9430 & 49.0 & 25.4 & 18.3 & 7.30 & 1.9 & 1144 \\
\hline RP11 & $6806.6-6955.3$ & $\mathrm{O}_{2} y$ & 0.8250 & 76.5 & 14.7 & 7.60 & 1.20 & 5.2 & 1187 \\
\hline RP1101 & $6756.0-6985.0$ & $\mathrm{O}_{3} l$ & 0.8127 & 81.8 & 12.5 & 4.10 & 1.60 & 6.5 & 1225 \\
\hline RP1-2 & $6830.0-6970.0$ & $\mathrm{O}_{3} t$ & 0.8030 & 84.6 & 11.1 & 2.50 & 1.80 & 7.6 & 1203 \\
\hline RP14 & $6823.4-6967.0$ & $\mathrm{O}_{3} l$ & 0.8214 & 81.9 & 12.1 & 4.80 & 1.20 & 6.8 & 1169 \\
\hline RP3 & $6977.2-7040.0$ & $\mathrm{O}_{2} y$ & 0.7900 & 87.1 & 7.50 & 3.40 & 2.00 & 11.6 & 1069 \\
\hline RP3001 & $6949.4-7003.0$ & $\mathrm{O}_{3} l$ & 0.8009 & 77.8 & 15.8 & 5.10 & 1.30 & 4.9 & 862 \\
\hline RP3013 & $7012.0-7135.0$ & $\mathrm{O}_{1-2} \mathrm{y}$ & 0.7960 & 88.6 & 8.10 & 2.50 & 0.80 & 10.9 & 1216 \\
\hline RP302C & $7352.0-7385.0$ & $\mathrm{O}_{2} y$ & 0.8810 & 68.7 & 19.4 & 7.00 & 4.90 & 3.5 & 1446 \\
\hline RP3-1 & $6966.9-7066.0$ & $\mathrm{O}_{2} y$ & 0.7920 & 84.7 & 9.40 & 2.30 & 3.60 & 9.0 & 1200 \\
\hline RP4-1 & $6605.1-6745.0$ & $\mathrm{O}_{3} l$ & 0.8621 & 62.7 & 20.4 & 12.3 & 4.60 & 3.1 & 721 \\
\hline RP5C & $6651.0-7273.5$ & $\mathrm{O}_{3} l$ & 0.8303 & 84.4 & 10.1 & 3.90 & 1.70 & 8.4 & 934 \\
\hline RP6C & $6534.0-7220.0$ & $\mathrm{O}_{3} l$ & 0.8116 & 51.1 & 9.90 & 37.3 & 1.60 & 5.2 & 851 \\
\hline RP7 & $6692.0-6914.0$ & $\begin{array}{l}\mathrm{O}_{3} l- \\
\mathrm{O}_{1-2} y\end{array}$ & $\approx 1.00$ & 36.4 & 23.3 & 4.60 & 35.7 & 1.6 & 678 \\
\hline RP7 & $6849.8-6875.0$ & $\mathrm{O}_{2} y$ & $\approx 1.00$ & 33.5 & 23.3 & 6.70 & 35.5 & 1.4 & 844 \\
\hline RP7C & $6692.1-6980.0$ & $\mathrm{O}_{3} l$ & 0.8230 & 75.4 & 16.4 & 5.70 & 2.50 & 4.6 & 1091 \\
\hline RP13 & $6853.6-6890.0$ & $\mathrm{O}_{3} l$ & 0.8080 & 74.9 & 16.9 & 2.70 & 5.50 & 4.4 & 1045 \\
\hline RP13C & $6684.7-6985.0$ & $\mathrm{O}_{3} l$ & 0.8060 & 78.2 & 13.9 & 7.20 & 0.70 & 5.6 & 1085 \\
\hline RP7004C & $6773.0-7326.0$ & $\mathrm{O}_{3} l$ & 0.8160 & 78.6 & 12.1 & 7.20 & 2.10 & 6.5 & 830 \\
\hline RP7006 & $6862.6-6975.0$ & $\mathrm{O}_{3} l-\mathrm{O}_{2} y$ & 0.8099 & 74.9 & 13.9 & 7.20 & 4.00 & 5.4 & 934 \\
\hline RP7008 & $6853.0-6970.0$ & $\mathrm{O}_{3} l$ & 0.8082 & 61.5 & 18.6 & 7.90 & 12.0 & 3.3 & 828 \\
\hline RP8 & $6914.9-6949.0$ & $\mathrm{O}_{2} y$ & 0.8040 & 80.4 & 14.3 & 3.70 & 1.60 & 5.6 & 882 \\
\hline RP8001 & $6675.0-7057.7$ & $\mathrm{O}_{3} l$ & 0.8165 & 79.5 & 12.0 & 6.10 & 2.40 & 6.6 & 726 \\
\hline
\end{tabular}




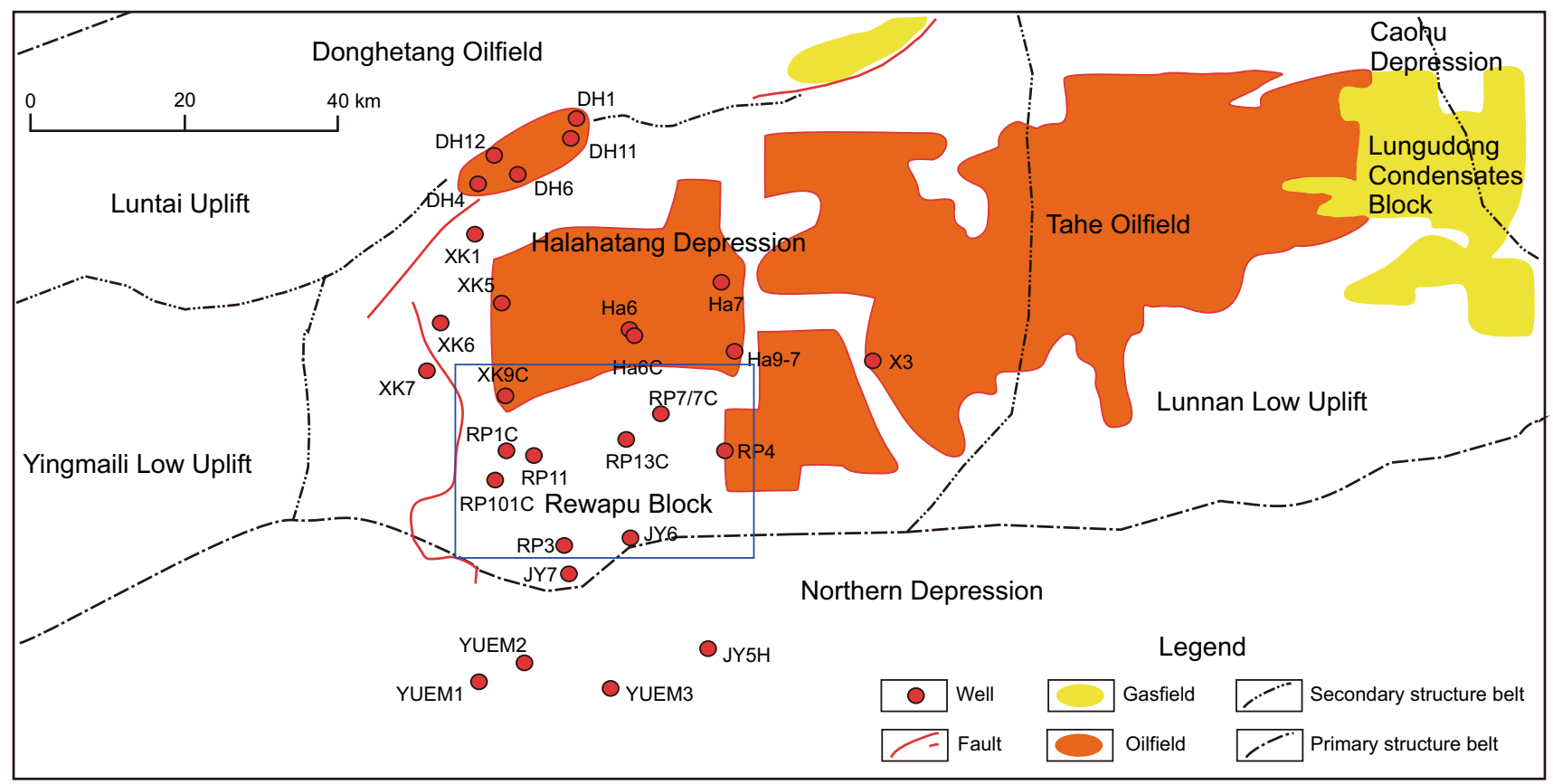

Fig. 1 Map of the location and schematic structure of Rewapu Block of the Halahatang Oilfield, Tarim Basin (after Sun et al. 2015)

\section{Experimental}

A total of 27 oil samples were collected from the carbonate reservoir of the $\mathrm{O}_{3} l, \mathrm{O}_{2} y$ and $\mathrm{O}_{1-2} y$ formations. Following the conventional geochemical analysis procedure, all oils were separated into saturated, aromatic, asphaltenes and NSO fractions (Fang et al. 2017a).

The saturated and aromatic fractions were further geochemically analyzed by gas chromatography-mass spectrometry (GC-MS), which was performed on an Agilent 5895i GC-MS system equipped with an HP-5MS (5\% phenyl methylpolysiloxane) fused silica capillary column. For the saturated fractions, the GC-MS system was used under the following conditions: (1) The initial GC oven temperature was set at $50{ }^{\circ} \mathrm{C}$ for $1 \mathrm{~min}$, then ramped to $120{ }^{\circ} \mathrm{C}$ at a rate of $20^{\circ} \mathrm{C} / \mathrm{min}$, subsequently to $310{ }^{\circ} \mathrm{C}$ at $3{ }^{\circ} \mathrm{C} / \mathrm{min}$ and finally kept isothermal for $25 \mathrm{~min}$. For the aromatic fractions, the $\mathrm{GC}$ oven temperature was initially set at $50{ }^{\circ} \mathrm{C}$ for $1 \mathrm{~min}$, then gradually increased to $310{ }^{\circ} \mathrm{C}$ at a rate of $3{ }^{\circ} \mathrm{C} / \mathrm{min}$ and finally held isothermally for 16 min. Helium was utilized as the carrier gas. The MS was operated in electron impact (EI) mode with an ionization energy of $70 \mathrm{eV}$ and a scanning range of 50-600 Da.

\section{Results and discussion}

\subsection{Physical properties and bulk compositions}

The physical properties of the Rewapu oils cover a wide spectrum of density, ranging from $0.79 \mathrm{~g} / \mathrm{cm}^{3}$ to approximately $1.00 \mathrm{~g} / \mathrm{cm}^{3}$. Most of the oils in the northern part of the Halahatang Block (Ha6 Block), e.g., oils from Wells Ha7, Ha7-1, Ha7-7 and Ha9-6 in this study, are heavy to ultra-heavy oils. Most of the oils in the Rewapu Block (south-central part of the Halahatang region) are light oils with density generally lower than $0.82 \mathrm{~g} / \mathrm{cm}^{3}$. Of particular interest are oils from Wells RP7 and RP101C; these oils have extremely high density $\left(>1.00 \mathrm{~g} / \mathrm{cm}^{3}\right)$, which are apparently different from those in adjacent wells, making Well RP7 and Well RP101C oils unique. In particular, Well RP7C, which is the sidetracking well of RP7 and located in the same site, produced light oils (Table 1).

The bulk group compositions of oils also show large variation, especially for the saturated fraction (Table 1). Most of the light oils in the Rewapu Block have high contents of saturated hydrocarbons, generally from $60 \%$ to $80 \%$ (Table 1). However, three heavy oils from Wells RP101C and RP7 have quite low saturated hydrocarbon contents, with $49.0 \%$ for Well RP101C and 33.5\%-36.4\% for Well RP7. Heavy oils from Wells Ha7, Ha7-1, Ha7-7 and Ha9-6 in the Ha6 Block have also relatively low contents of saturated hydrocarbons.

The saturated/aromatic hydrocarbon ratios are primarily controlled by maturity and secondary alteration. Most oils 
from the Rewapu Block have relatively higher ratios (3.5-6.0). Three heavy oil samples from Wells RP101C and RP7 have quite lower saturated/aromatic hydrocarbon ratios $(<2.0)$. The heavy oils from Wells Ha7, Ha7-1, Ha7-7 and Ha9-6 have relatively lower ratios. Particularly, the Well Ha7 heavy oil has extremely low value $(0.7)$. Since all oils were sampled at the same time and were analyzed by the same experimental procedures, the effects of evaporation and laboratory analysis can be ruled out. Therefore, the apparent difference in oil bulk compositions within these samples indicates different origins and/or different exposures to secondary alteration processes after the oil generation and expulsion.

\subsection{Oil-oil correlation}

Although oils in the Halahatang Oilfield have experienced multiple oil charging processes and complex secondary alteration, some molecular markers that are resistant to secondary alteration and independent of migration and thermal maturity can still be used for oil-oil correlation. All oils analyzed in the Rewapu Block are characterized by low $\mathrm{Pr} / \mathrm{Ph}$ ratios (relative abundances of pristane to phytane) (Fig. 2), higher relative contents of dibenzothiophenes (Table 1), lower ratios of $\mathrm{C}_{21} / \mathrm{C}_{23}$ tricyclic terpanes (Fig. 3) and relatively lower $\mathrm{C}_{28}$ regular steranes (Fig. 4). The biomarker compositions of all these oils are similar to those of oils from other wells in the Halahatang Oilfield (Xiao et al. 2016; Fang et al. 2016). Therefore, oils in the Rewapu Block are genetically identical and were derived from the same source kitchen. Previous studies (Chang et al. 2013a) indicated that Paleozoic oils in the Halahatang Oilfield geochemically correlate well with Middle-Upper Ordovician source rocks. They have experienced similar oil charging events (Wang et al. 2008; Chang et al. 2013b; Xiao et al. 2016). The differences in biomarker compositions of oils are mainly controlled by the differences in oil accumulation conditions and secondary alteration.

\subsection{Oil charging processes}

The overall oil migration orientation and filling pathway of the entire Halahatang Oilfield are generally from south to north (Xiao et al. 2016; Fang et al. 2017a; Li et al. 2018). Some molecular geochemical indictors for oils in the Rewapu Block have been reported by Xiao et al. (2016) and Li et al. (2018). The MDR (methyldibenzothiophene ratio: the relative abundance of 4-methyldibenzothiophene to 1-methyldibenzothiophene), $\mathrm{TMNr}$ (trimethylnaphthalene ratio) and other parameters all show a decreasing trend from south to north. Therefore, the predicted source kitchen/bed should be in the southern part of the Halahatang region.
By combining homogenization temperatures of fluid inclusions in reservoir rocks and reconstructed stratigraphic burial and geothermal histories, Ni et al. (2016) and Xiao et al. (2016) determined the timing and episodes of oil charging in the Rewapu Block. These studies suggested that the discovered Paleozoic carbonate oils in the Rewapu Block have undergone two petroleum filling events: The former charging event occurred in the Middle to Late Silurian and the latter one in the Miocene to Pliocene. The oil filling history is generally consistent with those in other blocks in the Halahatang Oilfield (Chang et al. 2013b; Li et al. 2018) and Ordovician carbonate reservoirs in other oilfields of the Tabei Uplift (Wang et al. 2008; Liao et al. 2010).

\subsection{Oil accumulation conditions}

The oils charged in the latter episode occurring in the Miocene to Pliocene were dominated by light oils with relatively higher maturity ( $\mathrm{Li}$ et al. 2018). The reservoirs usually have thick seal rocks and good preservation conditions. Therefore, the physical properties and chemical compositions of mixed oils are mainly controlled by the preservation conditions for reservoir oils from the early charging phase.

The early phase of Ordovician petroleum charging was determined to $\sim 419-410 \mathrm{Ma}$ (Xiao et al. 2016) associated with rapid subsidence of thick Silurian Formations. The Silurian Formations deposited widely after the wide erosion of the Upper Ordovician and mainly consist of fine clastics deposited in a shallow littoral and tidal flat environment in the Tabei Uplift. The maximum thickness can reach $3600 \mathrm{~m}$ in the Manjiaer Depression (Zhu et al. 2001). However, the present Silurian stratum is missing in most of the sections in the Tabei Uplift due to severe erosion caused by lifting in the late stage of Silurian and Early Devonian ( $\mathrm{Li}$ et al. 2010). Therefore, the thickness of residual Silurian plus Upper Ordovician overlying the Lower-Middle Ordovician carbonate reservoir is a critical factor controlling the preservation conditions for reservoir oils from the early charging phase.

A recent study shows that the thickness of Upper Ordovician and Silurian strata is generally lower than $600 \mathrm{~m}$ in the northern part of the Halahatang (the most part of the Ha6 Block) (Ni et al. 2016), and the oils in this region are characterized by heavy oil, with an apparent "hump" on the baseline of gas chromatograms of saturated hydrocarbons and the presence of 25-norhopanes ( $\mathrm{Li}$ et al. 2018). Apparently, oils charged in this region during the early phase were subjected to severe biodegradation.

It is generally believed that biodegradation levels generally decrease with increasing reservoir temperature and it 
TIC

(a)

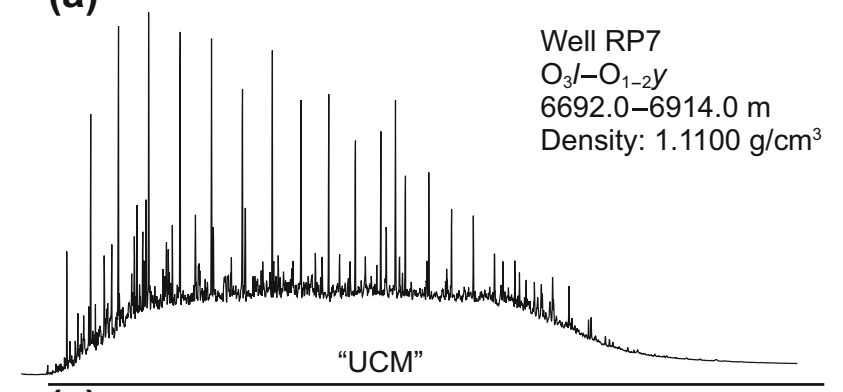

(c)

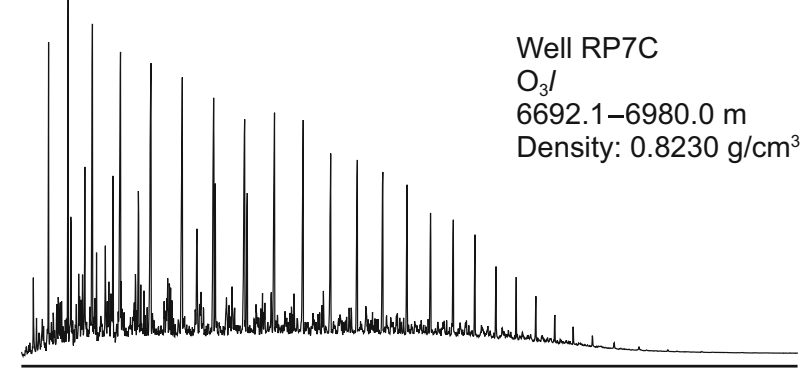

(e)

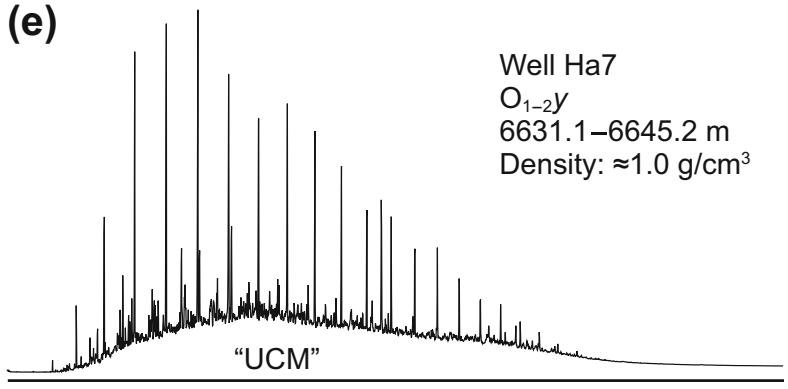

Relative retention time

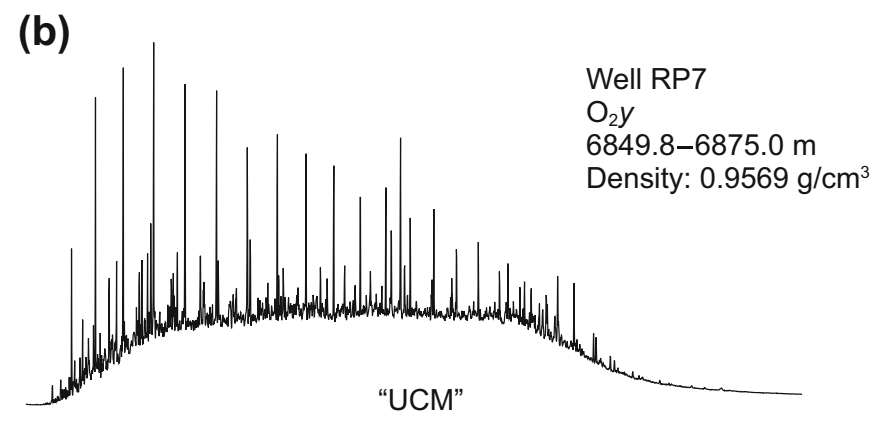

(d)

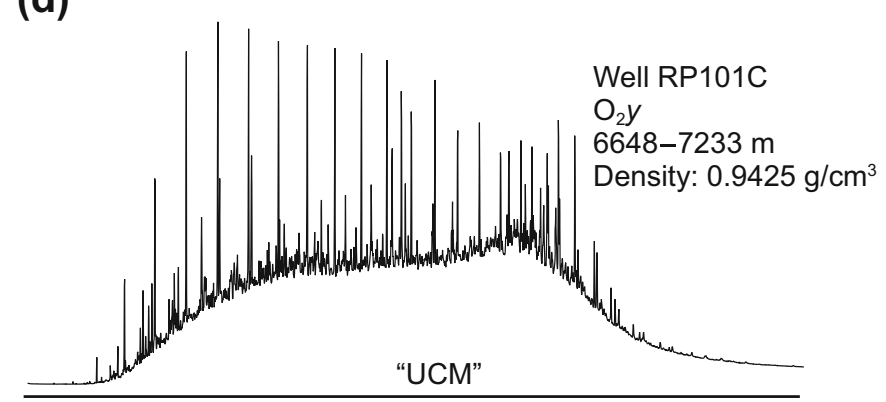

(f)

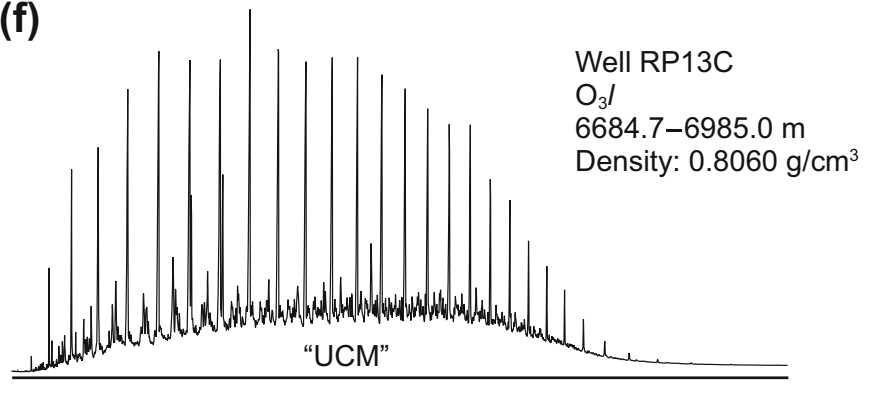

Relative retention time

Fig. 2 TIC (total ion current) of saturated fractions of oils from Wells RP7 and RP7C and other representative wells

ceases at about $75-80{ }^{\circ} \mathrm{C}$ (Connan 1984; Palmer 1984). It is also commonly accepted that the Tarim Basin is a "cool basin" with the present-day geothermal gradient of approximately $2.0^{\circ} \mathrm{C} / 100 \mathrm{~m}$ (Li et al. 2005, 2010). However, the geothermal gradient could have reached 3.2-3.5 ${ }^{\circ} \mathrm{C} / 100 \mathrm{~m}$ during the Sinian to Early Paleozoic. The surface temperature is estimated at $20-25{ }^{\circ} \mathrm{C}$ in the Late Ordovician ( $\mathrm{Li}$ et al. 2010). Therefore, the temperature is lower than approximately $45^{\circ} \mathrm{C}$ at depths shallower than $600 \mathrm{~m}$. Significant biodegradation can considerably modify the physical properties and chemical compositions of reservoir oils filled during the early charging event. Most of the oils in the Rewapu Block are light oils with no apparent "hump" on the baseline of the gas chromatograms of their saturated hydrocarbons (Fig. 2), and no 25-norhopanes were detected. The thickness of Upper Ordovician and Silurian caprocks in the Rewapu Block is more than $800 \mathrm{~m}$ and generally increases from north to south. For example, the thickness of the residual Upper Ordovician plus Silurian is $867 \mathrm{~m}$ for Well RP7 and is greater than $1700 \mathrm{~m}$ in the YM Block (Li et al. 2018). The oils in the southern part of the Halahatang region are dominated by light oils. Therefore, we can infer that the oils with Upper Ordovician plus Silurian caprocks thicker than c.a. $800 \mathrm{~m}$ have not been subjected to significant biodegradation.

\subsection{The extent of biodegradation and water washing}

It is difficult to evaluate the extent of biodegradation or water washing since the oils present in Ordovician reservoirs are mixtures of oils filled by two distinct charging events. Some commonly used molecular ratios indicating 
$m / z 191$
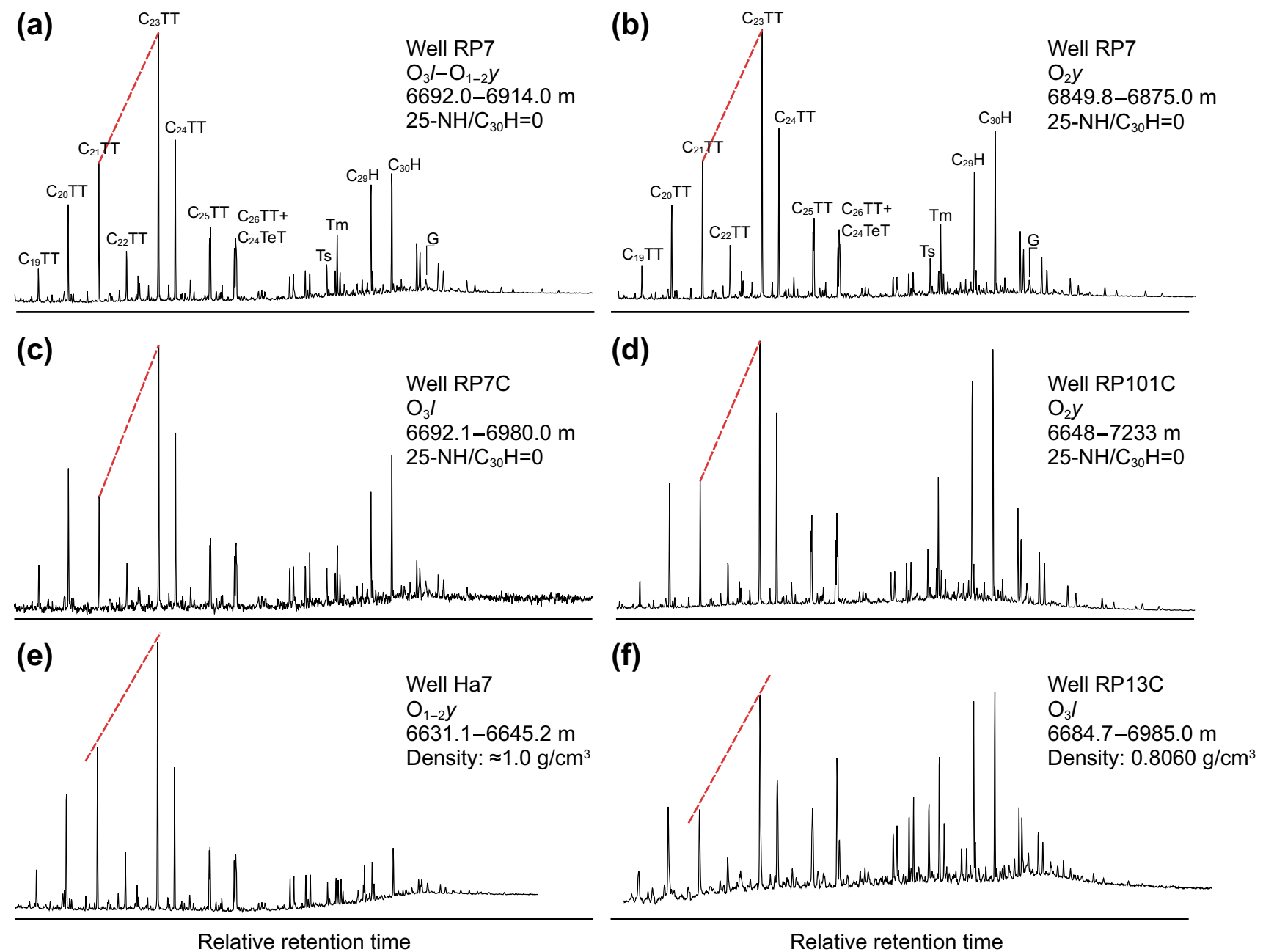

Fig. 3 Mass chromatograms $(\mathrm{m} / \mathrm{z}, 191)$ showing the distribution of tricyclic terpanes and hopanes in oils from Wells RP7 and RP7C and other representative wells

the degree of biodegradation, e.g., $\mathrm{Pr} / n \mathrm{C}_{17}$ (the relative abundances of pristane to normal $\mathrm{C}_{17}$ alkane) and $\mathrm{Ph} / n \mathrm{C}_{18}$ (the relative abundance of phytane to normal $\mathrm{C}_{18}$ alkane), cannot be applied to assess the degree of biodegradation or other in situ reservoir alterations.

In the northern part of the Halahatang region (Ha6 Block), the heavy oils contain both a full range of $n$ alkanes (indicating no biodegradation) and 25-norhopane series/baseline "hump" in gas chromatograms of saturated hydrocarbons (Chang et al. 2012; Li et al. 2018), indicating the severely biodegraded oils were mixed with undegraded petroleum. The 25-norhopanes (also called 10-demethyl hopanes or demethylated hopanes) are $\mathrm{C}_{26}-\mathrm{C}_{34}$ compounds which have similar chemical structure to those of regular hopanes, except for the absence of the methyl group at the $\mathrm{A} / \mathrm{B}$ ring junction (Peters et al. 2005). Figure $5 \mathrm{~d}$ shows the distribution of hopanes $(\mathrm{m} / \mathrm{z}, 191)$ and 25-norhopanes $(\mathrm{m} / \mathrm{z}$
177) for heavy oils of representative Well Ha7-16 in the Ha6 Block. All 25-norhopane series, including $\mathrm{C}_{29}$ 25-nor$17 \alpha(\mathrm{H}), 21 \beta(\mathrm{H})$-hopane (corresponding to $\mathrm{C}_{30}$ $17 \alpha(\mathrm{H}), 21 \beta(\mathrm{H})$-hopane) and each pair of $\mathrm{C}_{30}-\mathrm{C}_{34} 25$-norhopane $(22 \mathrm{~S}+22 \mathrm{R})$ epimers (corresponding to $\mathrm{C}_{31}-\mathrm{C}_{35}$ $17 \alpha(\mathrm{H}), 21 \beta(\mathrm{H})$-hopane), have been detected. It is generally believed that a high abundance of 25-norhopanes is evidence for severe biodegradation $[\geq \operatorname{rank} 6$ on the scale of biodegradation proposed by Peters et al. (2005)]. The relative abundance of 25-norhopanes to hopanes can be used to assess the extent of biodegradation among severely biodegraded oils (rank 6-9) (Peters et al. 2005). Due to the mixture of un-biodegraded oils with severely biodegraded oils, this ratio cannot be used to accurately evaluate the extent of biodegradation. However, it is certain that the heavy oils in the northern part of the Halahatang region have undergone severe biodegradation. 
$m / z 217$
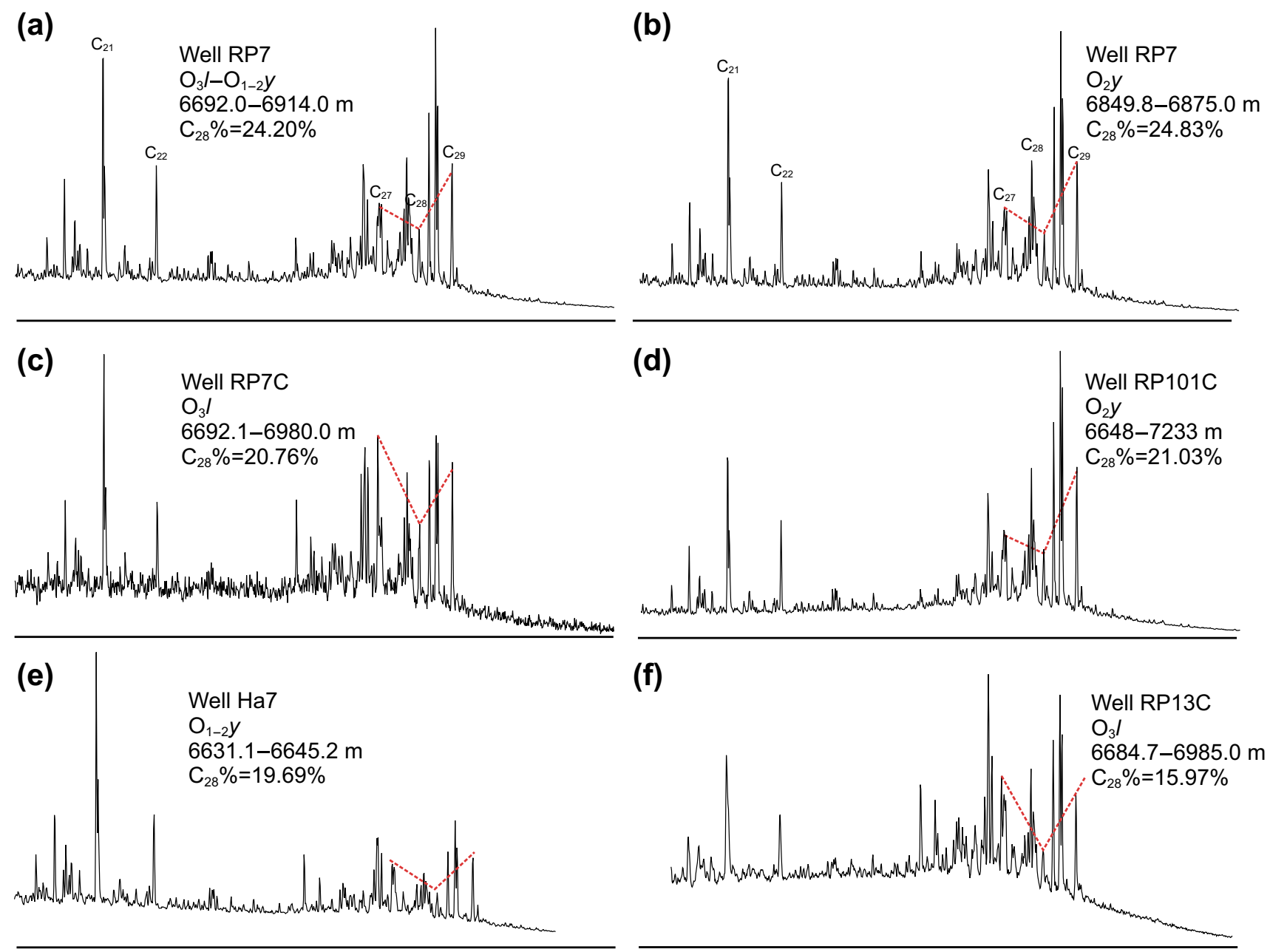

Relative retention time

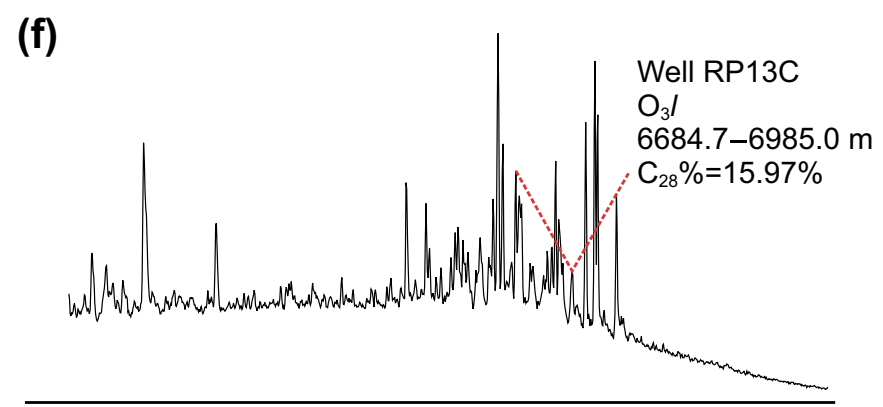

Relative retention time

Fig. 4 Mass chromatograms $(\mathrm{m} / \mathrm{z}$ 217) showing the distribution of regular steranes in oils from Wells RP7 and RP7C and other representative wells

Although the occurrence of hopane degradation with no 25-norhopanes was reported in many cases (Seifert and Moldowan 1979; Goodwin et al. 1983; Connan 1984; Moldowan et al. 1991), most of the oils in the Rewapu Block apparently did not experience significant biodegradation (Fig. 5a), because most of these oils are light oils with no "hump" on the baseline of the gas chromatograms (Fig. 2).

Exceptionally, three oils from Wells RP7 and RP101C in the Rewapu Block have different physical properties and organic geochemical characteristics. They are heavy oils with an apparent "hump" on the baseline of gas chromatograms (Fig. 2). However, no 25-norhopanes were detected in these oils. Previous studies (Xiao et al. 2016; Li et al. 2018) showed that these wells have similar petroleum charging histories to other oil reservoirs in this area (e.g., RP3-1; Ni et al. 2016). Therefore, the local petroleum accumulation conditions exerted a significant impact on the chemical compositions and physical properties of oils.

Experimental data by Palmer (1984) suggest that the sulfur-bearing compounds are approximately twice as soluble in water as aromatic hydrocarbons of similar molecular weight. These heterocyclic compounds are resistant to biodegradation and therefore tend to be more concentrated in biodegraded oils. Dibenzothiophene (DBT) and its alkylated homologues are the most important organosulfur compounds in oils and source rock extracts, and these can be detected by routine GC-MS analysis of aromatic fractions. The distribution of alkylated DBTs is influenced by organic facies (Hughes 1984; Hughes et al. 1995; Radke et al. 2000; Li et al. 2013) and thermal maturity of organic matter (Radke et al. 1986; Radke 1988; Budzinski et al. 1993; Chakhmakhchev et al. 1997; Li et al. 2014b). 

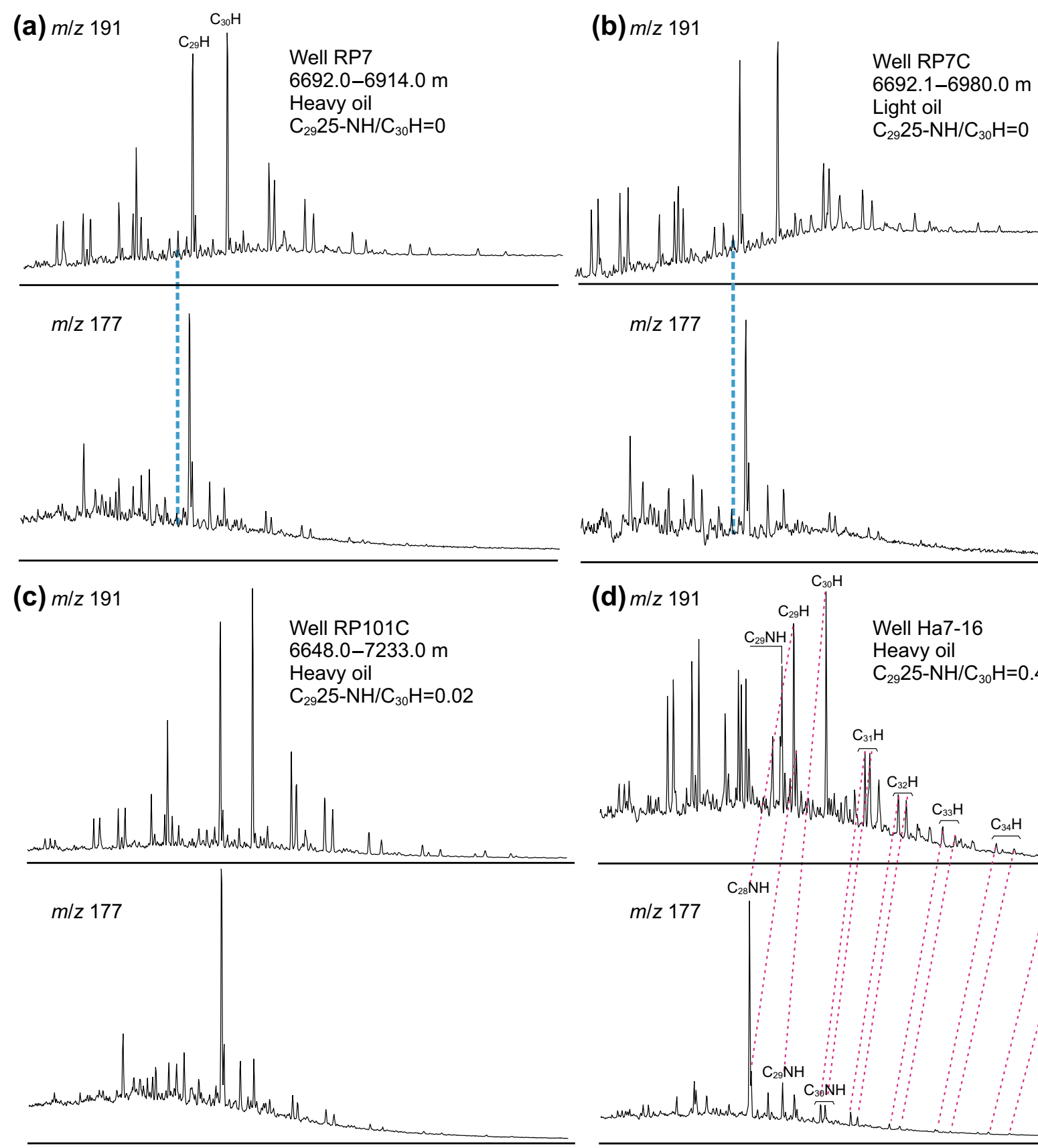

Relative retention time
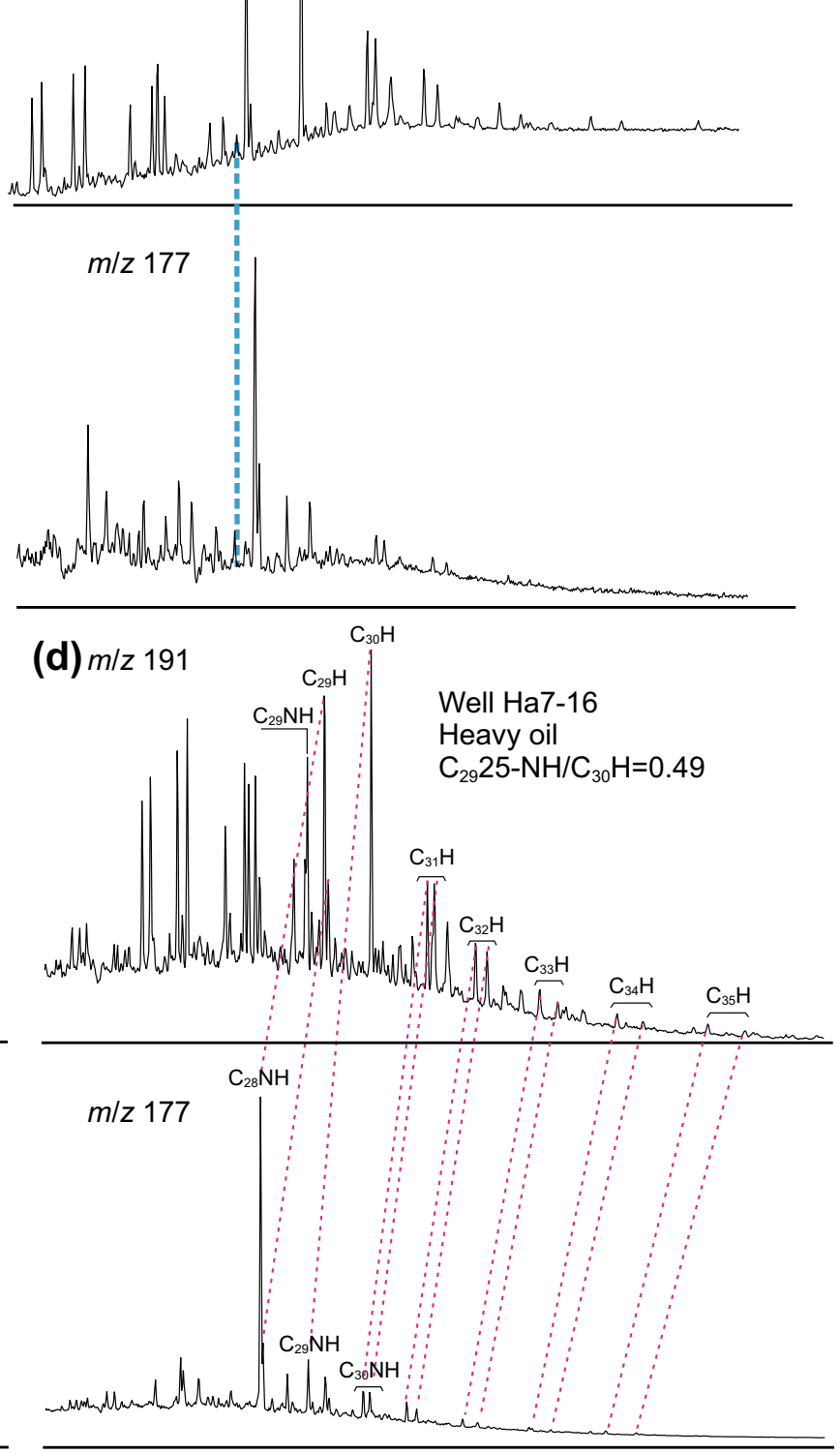

Relative retention time

Fig. 5 Mass chromatograms $(\mathrm{m} / \mathrm{z}, 191 ; \mathrm{m} / \mathrm{z}$ 177) showing the distribution of hopane and 25-norhopane series in oils from Wells RP7 and RP7C and others

As demonstrated by previous studies, the relative abundances of methylated DBT isomers and the absolute concentrations in oils are also relative to migration distance. Therefore, the ratios of methylated DBT isomers and concentrations of total DBTs for oils derived from same source bed/kitchen can be applied to trace oil migration direction and charging pathway (Wang et al. 2004; Li et al.
2008, 2014a; Fang et al. 2016, 2017a, b). Except for one case study in a Tertiary sandstone reservoir in the Beibuwan Basin, South China Sea, we also found that the absolute concentration of DBTs was not an effective indicator for tracing oil migration orientation in Tarim Paleozoic carbonate reservoirs ( $\mathrm{Li}$ et al., unpublished data). The water washing alteration by the interaction between oil 


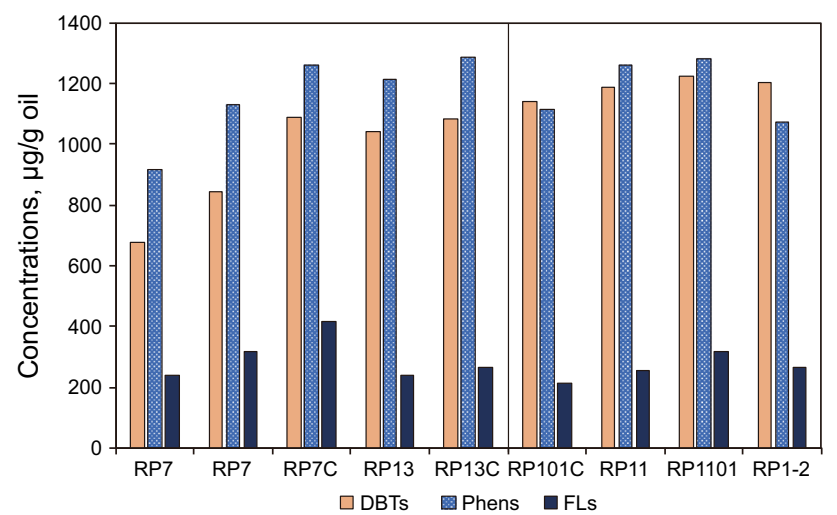

Fig. 6 Effect of water washing on the absolute concentrations of alkylated dibenzothiophenes (DBTs), $\mathrm{C}_{0}-\mathrm{C}_{3}$ phenanthrenes (Phens) and $\mathrm{C}_{0}-\mathrm{C}_{2}$ fluorenes (FLs) in oils from RP7, RP101C and adjacent wells

and formation water in karst reservoirs is likely to be the principle reason.

Water washing results in a significant reduction in the concentration of polycyclic aromatic hydrocarbons, such as $\mathrm{C}_{0}-\mathrm{C}_{3}$ phenanthrenes and $\mathrm{C}_{0}-\mathrm{C}_{2}$ fluorenes, in Well RP7 heavy oil. This is lower than those from the light oils from Well RP7C and adjacent Wells RP13 and RP13C (Fig. 6). The migration fractionation and variations in maturity and depositional environment are minor for oils from wells located within a distance of less than $2 \mathrm{~km}$ (refer to Xiao et al. 2016). Therefore, water washing may be the principle type of secondary alteration leading to the depletion of $\mathrm{C}_{0^{-}}$
$\mathrm{C}_{3}$ phenanthrenes and $\mathrm{C}_{0}-\mathrm{C}_{2}$ fluorenes. The heavy oil in Well RP101C also shows relatively lower $\mathrm{C}_{0}-\mathrm{C}_{3}$ phenanthrenes and $\mathrm{C}_{0}-\mathrm{C}_{2}$ fluorenes concentrations compared to oils from neighboring Wells RP11, RP1101 and RP1-2. The absolute concentrations for alkylated dibenzothiophenes (DBTs) further demonstrated the effect of water washing (Table 1, Fig. 6). Oils from Wells RP7 and RP101C also have relatively lower concentration of DBTs relative to neighboring wells.

Since biodegradation is commonly associated with water washing, the biodegradation for oils in Wells RP7 and RP101C cannot be exclusively ruled out due to the UCM chromatographic baseline. However, the influence of biodegradation might be only slight to moderate due to lack of 25-norhopanes.

Wells RP7 and RP101C present certain conditions favorable for water washing. Figures 7 and 8 illustrate the cross sections showing the geological background of reservoirs in Wells RP7 and RP101C and adjacent wells. It shows that the oil reservoirs of Wells RP7 and RP101C contact formation waters. On the contrary, no such formation water occurs for the oil reservoir of Well RP7C, which is a sidetracking well of RP7 and located in the same site (Fig. 7). Therefore, the oil from Well RP7C is light oil with a relatively higher concentration of DBTs. This suggests that the contact with local formation water in the reservoir may modify the physical properties and chemical compositions of oil in the Rewapu Block.

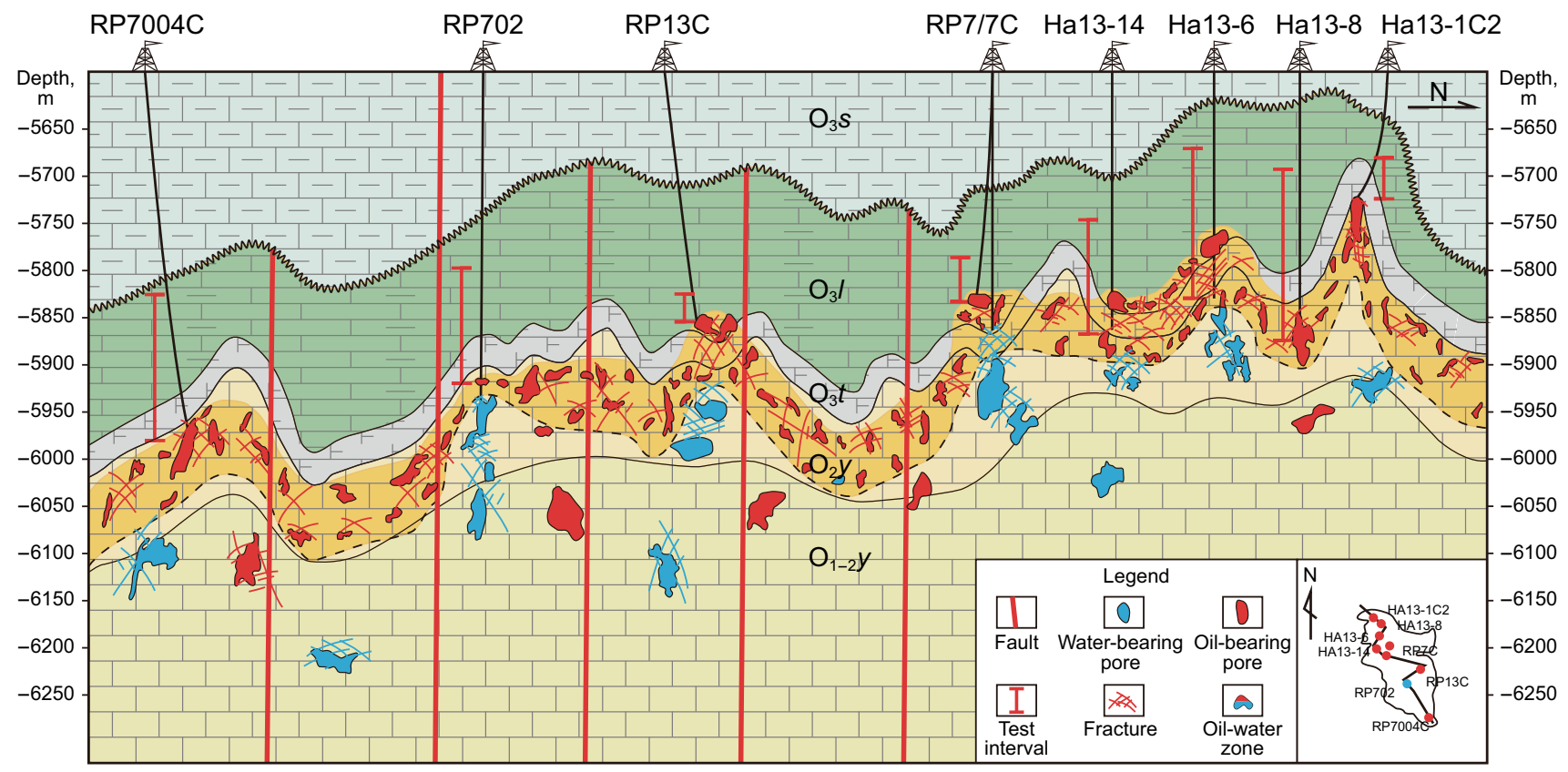

Fig. 7 Cross section showing the geological background of Wells RP7 and RP7C reservoir in the Halahatang Oilfield 


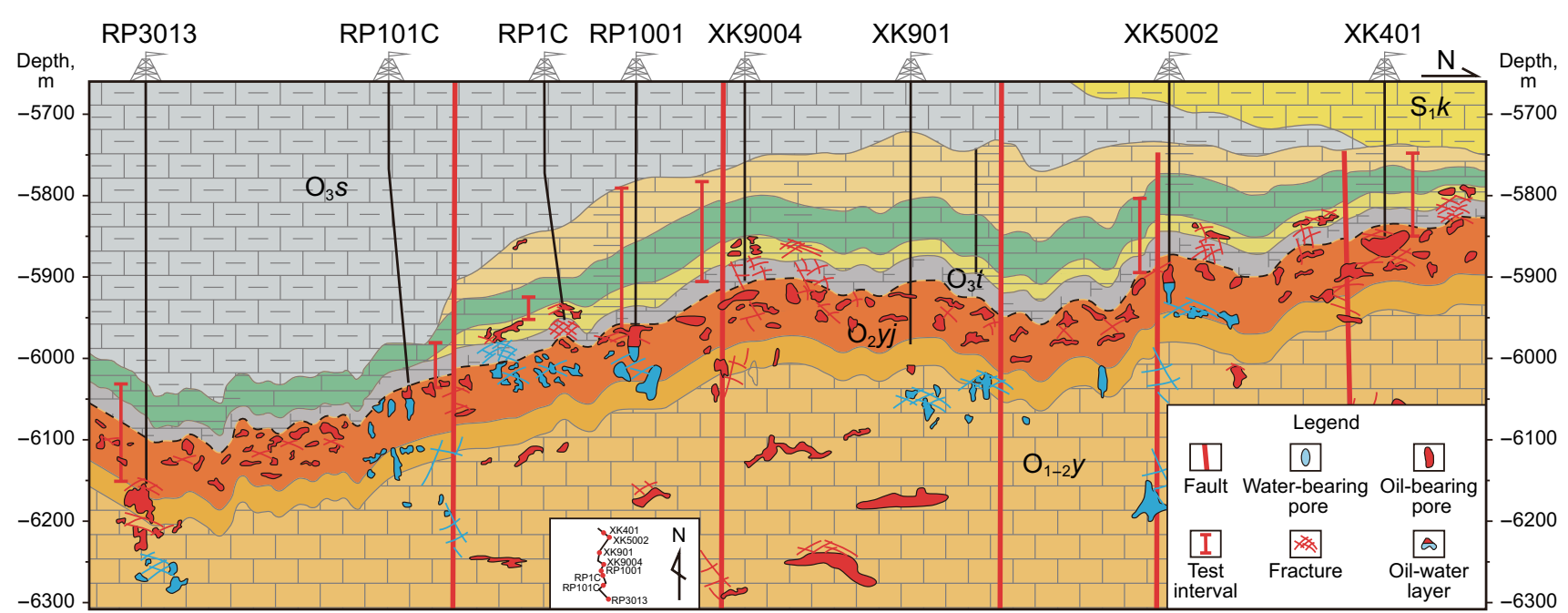

Fig. 8 Cross section showing the geological background of the Well RP101C reservoir in the Halahatang Oilfield

\section{Conclusions}

The detailed geochemical characteristics of a suite of 27 oil samples from the Rewapu Block of the Halahatang Oilfield in the Tabei Uplift of the Tarim Basin (NW China) were studied to evaluate their origin and secondary alteration processes. These oils together with other oils in the Ordovician carbonate reservoirs of the Halahatang region were generated from the same source kitchen and have experienced similar oil charging processes.

Most of the oils in the Rewapu Block are light and normal oils, which are distinctly different from those heavy oils in the northern part of the Halahatang region. Significant biodegradation can be eliminated due to lack of 25-norhopanes and the absence of a "hump" on the baseline of chromatograms. Exceptions are extremely heavy oils in Wells RP7 and RP101C. These oils have an apparent chromatographic baseline "hump," but no 25-norhopanes. The alkylated dibenzothiophenes were apparently reduced. Therefore, biodegradation was not severe and water washing appears to be the principal factor causing the origin of heavy oils in Wells RP7 and RP101C. The local geological background presents conditions that are favorable for water washing alteration in these wells.

\footnotetext{
Acknowledgements This study was funded by the National Natural Science Foundation of China (Grant No. 41272158) and the Foundation of the State Key Laboratory of Petroleum Resources and Prospecting, China University of Petroleum, Beijing (PRP/open1710). The authors are grateful for the assistance of Shengbao Shi and Lei Zhu for the geochemical analyses of all selected samples. We would like to thank the Research Institute of Petroleum Exploration and Development of PetroChina for providing samples and data and for permission to publish this work. The authors would extend the acknowledgments to the editors and anonymous reviewers for their constructive suggestions.
}

Open Access This article is distributed under the terms of the Creative Commons Attribution 4.0 International License (http://creative commons.org/licenses/by/4.0/), which permits unrestricted use, distribution, and reproduction in any medium, provided you give appropriate credit to the original author(s) and the source, provide a link to the Creative Commons license, and indicate if changes were made.

\section{References}

Alexander R, Kagi RI, Woodhouse GW, et al. The geochemistry of some biodegraded Australian oils. APPEA J. 1983;23(1):53-63. https://doi.org/10.1071/AJ82006.

Budzinski H, Garrigues P, Radke M, et al. Use of molecular modeling as a tool to evaluate thermodynamic stability of alkylated polycyclic aromatic hydrocarbons. Energy Fuel. 1993;7(4):505-11. https://doi.org/10.1021/ef00040a011.

Cai C, Amrani A, Worden RH, et al. Sulfur isotopic compositions of individual organosulfur compounds and their genetic links in the Lower Paleozoic petroleum pools of the Tarim Basin, NW China. Geochim Cosmochim Acta. 2016;182:88-108. https:// doi.org/10.1016/j.gca.2016.02.036.

Cai C, Zhang C, Worden RH, et al. Application of sulfur and carbon isotopes to oil-source rock correlation: a case study from the Tazhong area, Tarim Basin, China. Org Geochem. 2015;83-84:140-52. https://doi.org/10.1016/j.orggeochem.2015. 03.012 .

Cai C, Dong H, Li H, et al. Mineralogical and geochemical evidence for coupled bacterial uranium mineralization and hydrocarbon oxidation in the Shashagetai deposit, NW China. Chem Geol. 2017;236:167-79. https://doi.org/10.1016/j.chemgeo.2006.09. 007.

Chakhmakhchev A, Suzuki M, Waseda A, et al. Geochemical characteristics of Tertiary oils derived from siliceous sources in Japan, Russia and USA. Org Geochem. 1997;27(7-8):523-36. https://doi.org/10.1016/S0146-6380(97)00073-9.

Chang X, Wang TG, Li Q, et al. Maturity assessment of severely biodegraded marine oils from the Halahatang Depression in Tarim Basin. Energ Explor Exploit. 2012;30(3):331-50. https:// doi.org/10.1260/0144-5987.30.3.331.

Chang X, Wang TG, Li Q, et al. Geochemistry and possible origin of petroleum in Palaeozoic reservoirs from Halahatang Depression. 
J Asian Earth Sci. 2013a;74:129-41. https://doi.org/10.1016/j. jseaes.2013.03.024.

Chang X, Wang TG, Li Q, et al. Charging of Ordovician reservoirs in the Halahatang Depression (Tarim Basin, NW China) determined by oil geochemistry. J Pet Geol. 2013b;36:383-98. https:// doi.org/10.1111/jpg.12562.

Cheng B, Wang TG, Chen Z, et al. Biodegradation and possible source of Silurian and Carboniferous reservoir bitumens from the Halahatang sub-depression, Tarim Basin, NW China. Mar Pet Geol. 2016;78:236-46. https://doi.org/10.1016/j.marpetgeo. 2016.09.023

Connan J. Biodegradation of crude oils in reservoirs. Adv Pet Geochem. 1984. https://doi.org/10.1016/b978-0-12-032001-1. 50011-0.

Cubitt JM, England WA. The geochemistry of reservoirs. London: Geol Soc Spec Publ.; 1995.

Cui J, Wang T, Li M, et al. Oil filling history of the Bashituo Oilfield in the Markit Slope, SW Tarim Basin, China. Pet Sci. 2013;10(1):58-64. https://doi.org/10.1007/s12182-013-0250-0.

England WA, MacKenzie AS, Mann DM, et al. The movement and entrapment of petroleum fluids in the subsurface. J Geol Soc. 1987;144:327-47. https://doi.org/10.1144/gsjgs.144.2.0327.

Fang R, Wang T, Li M, et al. Dibenzothiophenes and benzonaphthothiophenes: molecular markers for tracing oil filling pathways in the carbonate reservoir of the Tarim Basin, NW China. Org Geochem. 2016;91:68-80. https://doi.org/10.1016/j.orggeochem. 2015.11.004.

Fang R, Li M, Wang T, et al. Trimethyldibenzothiophenes: molecular tracers for filling pathways in oil reservoir. J Pet Sci Eng. 2017a;159:451-60. https://doi.org/10.1016/j.petrol.2017.09.058.

Fang R, Li M, Lü H, et al. Oil charging history and pathways of the Ordovician carbonate reservoir in the Tuoputai region, Tarim Basin, NW China. Pet Sci. 2017b;14(4):1-14. https://doi.org/10. 1007/s12182-017-0196-8.

Goodwin NS, Park PJD, Rawlinson T. Crude oil biodegradation under simulated and natural conditions. In: Bjoroy M, et al., editors. Advances in organic geochemistry. Chichester: Wiley; 1983. p. $650-8$.

Hemptinne JCD, Peumery R, Ruffier-Meray V, et al. Compositional changes resulting from the water-washing of a petroleum fluid. J Pet Sci Eng. 2001;29(1):39-51. https://doi.org/10.1016/S09204105(00)00089-9.

Huang H, Jin G, Lin C, et al. Origin of an unusual heavy oil from the Baiyinchagan depression, Erlian basin, northern China. Mar Pet Geol. 2003;20(1):1-12. https://doi.org/10.1016/S02648172(03)00038-2

Huang $\mathrm{S}$, Li M, Zhang $\mathrm{K}$, et al. Distribution and geochemical significance of phenylphenanthrenes and their isomers in selected oils and rock extracts from the Tarim Basin, NW China. Pet Sci. 2016;13(2):183-91. https://doi.org/10.1007/ s12182-016-0095-4.

Hughes WB. Use of thiophenic organosulfur compounds in characterizing crude oils derived from carbonate versus siliciclastic sources. AAPG Stud Geol. 1984;18:181-96.

Hughes WB, Holba AG, Dzou LIP. The ratios of dibenzothiophene to phenanthrene and pristane to phytane as indicators of depositional environment and lithology of petroleum source rocks. Geochim Cosmochim Acta. 1995;59:3581-98. https://doi.org/10. 1016/0016-7037(95)00225-O.

Hunt JM. Petroleum geochemistry and geology. New York: Freeman; 1979. p. 617. https://doi.org/10.1016/0012-8252(80)90008-2.

Jing ZJ. New progresses in research of China's typical superimposed basins and reservoiring of hydrocarbons (part II): taking Tarim Basin as an example. Oil Gas Geol. 2006;3:281-8. https://doi. org/10.11743/ogg20060301 (in Chinese).
Kuo LC. An experimental study of crude oil alteration in reservoir rocks by water washing. Org Geochem. 1994;21:465-79. https:// doi.org/10.1016/0146-6380(94)90098-1.

Lafargue E, Barker C. Effect of water washing on crude oil composition. AAPG Bull. 1988;73(3):263-76. https://doi.org/ 10.1306/2F703C8C13-1707-11D7-8645000102C1865D.

Lafargue E, Thiez PL. Effect of water washing on light ends compositional heterogeneity. Org Geochem. 1996;24:1141-50. https://doi.org/10.1016/S0146-6380(96)00095-2.

Li HL, Qiu NS, Jin ZJ, et al. Geothermal history of Tarim Basin. Oil Gas Geol. 2005;26(5):613-7. https://doi.org/10.11743/ ogg20050509 (in Chinese).

Li M, Wang T-G, Liu J, et al. Total alkyl dibenzothiophenes content tracing the filling pathway of condensate reservoir in the Fushan depression, South China Sea. Sci China Ser D Earth Sci. 2008;51(2):138-45. https://doi.org/10.1007/s11430-008-6025-6.

Li M, Wang T-G, Chen J, et al. Paleo-heat flow evolution of the Tabei Uplift in Tarim Basin, northwest China. J Asian Earth Sci. 2010;37(1):52-66. https://doi.org/10.1016/j.jseaes.2009.07.007.

Li M, Wang T, Lillis PG, et al. The significance of 24-norcholestanes, triaromatic steroids and dinosteroids in oils and CambrianOrdovician source rocks from the cratonic region of the Tarim Basin, NW China. Appl Geochem. 2012;27(8):1643-54. https:// doi.org/10.1016/j.apgeochem.2012.03.006.

Li M, Wang T-G, Zhong N, et al. Ternary diagram of fluorenes, dibenzothiophenes and dibenzofurans: indicating depositional environment of crude oil source rocks. Energy Explor Exploit. 2013;31:569-88. https://doi.org/10.1260/0144-5987.31.4.569.

Li M, Wang T-G, Shi S, et al. Benzonaphthothiophenes and alkyl dibenzothiophenes: molecular tracers for oil migration distances. Mar Pet Geol. 2014a;57:403-17. https://doi.org/10.1016/j.mar petgeo.2014.06.012.

Li M, Wang T-G, Shi S, et al. Oil maturity assessment using maturity indicators based on methylated dibenzothiophenes. Pet Sci. 2014b;11(2):234-46. https://doi.org/10.1007/s12182-014-03363.

Li M, Wang T-G, Xiao Z, et al. Practical application of reservoir geochemistry in petroleum exploration: a case study from a Paleozoic carbonate reservoir in the Tarim Basin (NW China). Energy Fuel. 2018;32(2):1230-41. https://doi.org/10.1021/acs. energyfuels.7b03186.

Li S, Pang X, Shi Q, et al. Origin of the unusually high dibenzothiophene concentrations in Lower Ordovician oils from the Tazhong Uplift, Tarim Basin, China. Pet Sci. 2011;8(4):382-91. https://doi.org/10.1007/s12182-011-0170-9.

Liao ZW, Zhang LH, Yang CP, et al. Geochemical characteristics of heavy oils from the east and west sides of Halahatang Depression, Tarim Basin, China: exemplified by Oils of LG7 and DH1-6-9. Geochimica. 2010;39(2):149-53.

Liu CG, Li XQ, Liu YL, et al. Positive carbon isotope excursions: global correlation and genesis in the Middle-Upper Ordovician in the northern Tarim Basin, Northwest China. Pet Sci. 2016;13(2):192-203. https://doi.org/10.1007/s12182-016-00963.

Ma AL, Zhang SC, Zhang DJ, et al. Organic geochemistry of TD-2 well in Tarim Basin. Xinjiang Pet Geol. 2003;26:148-51 (in Chinese).

Mi J, Zhang S, Chen J, et al. The distribution of the oil derived from Cambrian source rocks in Lunna area, The Tarim Basin, China. Chin Sci Bull. 2007;52(Suppl I):133-40. https://doi.org/10.1007/ s11434-007-6004-x.

Moldowan JM, Fago FJ, Carlson RMK, et al. Rearranged hopanes in sediments and petroleum. Geochim Cosmochim Acta. 1991;55(11):3333-53. https://doi.org/10.1016/0016-7037(91) 90492-N. 
Ni Z, Wang T-G, Li M, et al. An examination of the fluid inclusions of the well RP3-1 at the Halahatang Sag in Tarim Basin, northwest China: implications for hydrocarbon charging time and fluid evolution. J Pet Sci Eng. 2016;146:326-39. https://doi. org/10.1016/j.petrol.2016.04.038.

Palmer SE. Effect of water washing on $\mathrm{C}_{15}{ }^{+}$hydrocarbon fraction of crude oils from Northwest Palawan, Philippines. AAPG Bull. 1984;68(2):137-49. https://doi.org/10.1306/2FAD4609EA16F7-11D7-8645000102C1865D.

Peters KE, Moldowan JM. The biomarker guide: interpreting molecular fossils in petroleum and ancient sediments. New Jersey: Prentice Hall; 1993. p. 399.

Peters KE, Walters CC, Moldowan JM. The biomarker guide: biomarkers and isotopes in petroleum systems and earth history, vol. 2. New York: Cambridge University Press; 2005. p. 490. https://doi.org/10.1017/cbo9781107326040.

Philp RP. Correlation of crude oils from the San Jorges Basin, Argentina. Geochim Cosmochim Acta. 1983;47(2):267-75. https://doi.org/10.1016/0016-7037(83)90139-4.

Radke M, Welte DH, Willsch H. Maturity parameters based on aromatic hydrocarbons: influence of the organic matter type. Org Geochem. 1986;10(1):51-63. https://doi.org/10.1016/01466380(86)90008-2.

Radke M. Application of aromatic compounds as maturity indicators in source rocks and crude oils. Mar Pet Geol. 1988;5(3):224-36. https://doi.org/10.1016/0264-8172(88)90003-7.

Radke M, Vriend SP, Ramanampisoa LR. Alkyldibenzofurans in terrestrial rocks: influence of organic facies and maturation. Geochim Cosmochim Acta. 2000;64(2):275-86. https://doi.org/ 10.1016/S0016-7037(99)00287-2.

Seifert WK, Moldowan JM. The effect of biodegradation on steranes and terpanes in crude oils. Geochim Cosmochim Acta. 1979;43(1):111-26. https://doi.org/10.1016/0016-7037(79)900 51-6.

Sofer Z, Zumberge JE, Lay V. Stable carbon isotopes and biomarkers as tools in understanding genetic relationship, maturation, biodegradation, and migration of crude oils in the Northern Peruvian Oriente (Maranon) Basin. Org Geochem. 1986;10(1):377-89. https://doi.org/10.1016/0146-6380(86)900 37-9.

Sun H, Li S, Zhang B. Characteristics and genesis of marine hydrocarbons in the Halahatang Sag in the northern Tarim Basin. Pet Geol Exp. 2015;37(6):pp. 704-712720. https://doi.org/10. 11781/sysydz201506704.

Sun Y, Xu S, Lu H, et al. Source facies of the Paleozoic petroleum systems in the Tabei uplift, Tarim Basin, NW China: implications from aryl isoprenoids in crude oils. Org Geochem. 2003. https://doi.org/10.1016/s0146-6380(03)00063-9.

Talukdar S, Gallango O, Ruggiero A. Generation and migration of oil in the Maturin Subbasin, Eastern Venezuelan basin. Org Geochem. 1988;13(1):537-47. https://doi.org/10.1016/01466380(88)90074-5.

Tian H, Xiao X, Wilkins RWT, et al. Formation and evolution of Silurian paleo-oil pools in the Tarim Basin, NW China. Org
Geochem. 2008;39(9):1281-93. https://doi.org/10.1016/j.orggeo chem.2008.05.011.

Tissot BP, Welte DH. Petroleum formation and occurrence. Berlin: Springer; 1984. p. 699.

Volkman JK, Alexander R, Kagi RI, et al. Demethylated hopanes in crude oils and their applications in petroleum geochemistry. Geochim Cosmochim Acta. 1983;47(4):785-94. https://doi.org/ 10.1016/0016-7037(83)90112-6.

Volkman JK, Alexander R, Kagi RI, et al. Biodegradation of aromatic hydrocarbons in crude oils from the Barrow Sub-basin of Western Australia. Adv Org Geochem. 1984;6(84):619-32. https://doi.org/10.1016/0146-6380(84)90084-6.

Wang T-G, He F, Li M, et al. Alkyldibenzothiophenes: molecular tracers for filling pathway in oil reservoirs. Chin Sci Bull. 2004;49(22):2399-404. https://doi.org/10.1360/03wd0583.

Wang T-G, He F, Wang C, et al. Oil filling history of the Ordovician oil reservoir in the major part of the Tahe Oilfield, Tarim Basin, NW China. Org Geochem. 2008;39(11):1637-46. https://doi.org/ 10.1016/j.orggeochem.2008.05.006.

Waples DW, Machihara T. Biomarkers for geologists-a practical guide to the application of steranes and triterpanes in petroleum geology. AAPG methods in exploration series, No. 9. Tulsa: The America Association of Petroleum Geologists; 1991.

Xiao Z, Li M, Huang S, et al. Source, oil charging history and filling pathways of the Ordovician carbonate reservoir in the Halahatang Oilfield, Tarim Basin, NW China. Mar Pet Geol. 2016;73:59-71. https://doi.org/10.1016/j.marpetgeo.2016.02. 026.

Zhang S, Huang H. Geochemistry of Palaeozoic marine petroleum from the Tarim Basin, NW China: part 1. Oil family classification. Org Geochem. 2005;36(8):1204-14. https://doi.org/10. 1016/j.orggeochem.2005.01.013.

Zhang S, Hanson AD, Moldowan JM, et al. Paleozoic oil-source rock correlations in the Tarim Basin, NW China. Org Geochem. 2000;31(4):273-86. https://doi.org/10.1016/S0146-6380(00)000 03-6.

Zhang S, Huang H, Su J, et al. Geochemistry of Paleozoic marine oils from the Tarim Basin, NW China. Part 4: paleobiodegradation and oil charge mixing. Org Geochem. 2014;67(1):41-57. https:// doi.org/10.1016/j.orggeochem.2013.12.008.

Zhang S, Moldowan JM, Li M, et al. The abnormal distribution of molecular fossils in the pre-Cambrian and Cambrian: its biological significance. Sci China Ser D Earth Sci. 2002;45:193-9.

Zhao K, Zhang L, Zheng D, et al. A reserve calculation method for fracture-cavity carbonate reservoirs in Tarim Basin, NW China. Pet Explor Dev. 2015;42(2):277-82. https://doi.org/10.1016/ S1876-3804(15)30017-3.

Zhu G, Zhang S, Su J, et al. The occurrence of ultra-deep heavy oils in the Tabei Uplift of the Tarim Basin, NW China. Org Geochem. 2012;52:88-102. https://doi.org/10.1016/j.orggeochem.2012.08. 012.

Zhu XM, Wang GW, Xie QB. Sequence stratigraphy of Silurian in Tarim Basin. J Palaeogeogr. 2001;3(2):64-71 (in Chinese). 